This is a self-archived - parallel published version of this article in the publication archive of the University of Vaasa. It might differ from the original.

\title{
Nișkāmakarma: a philosophical analysis in light of the prisoner's dilemma and the concept of degrowth
}

Author(s): Lehtonen, Tommi

Title: Nișkāmakarma: a philosophical analysis in light of the prisoner's dilemma and the concept of degrowth

Year: $\quad 2019$

Version: Accepted manuscript

Copyright C)2019 Society for Indian Philosophy and Religion

Please cite the original version:

Lehtonen, T., (2019). Nișkāmakarma: a philosophical analysis in light of the prisoner's dilemma and the concept of degrowth. Journal of Indian philosophy and religion 24(Dec), 3-30. https://doi.org/10.5840/jipr2019241 


\section{Nișkāmakarma: A Philosophical Analysis in Light of the Prisoner's Dilemma and the Concept of Degrowth}

Tommi Lehtonen

University of Vaasa, Finland

\section{Abstract}

The prisoner's dilemma famously shows that individuals seeking their own benefit end up with a worse outcome than could be achieved through cooperation. This dilemma provides an effective but neglected method for the study of the Hindu principle of "desireless action" (nișkämakarma). In the context of the prisoner's dilemma, one or the other of the following decision-making strategies is feasible for prisoners who want to follow the principle of "desireless action": (1) to be indifferent and to leave the decision to chance (e.g. by arbitrarily drawing lots) or (2) to pursue the common good or the benefit of the other (by remaining silent) instead of seeking primarily to benefit oneself (by confessing). The second strategy is more appropriate assuming the following: the followers of the principle of "desireless action" can be goal-oriented and target-driven, as long as unselfish goals are considered, while remaining indifferent and non-attached in terms of personal benefit. This interpretation is tested and further discussed in this article in light of the values of the modern environmental and anti-consumerist degrowth movement. A nonprofit orientation and the emphasis on duties are shared by the concepts of degrowth and nișkāmakarma. Social- or reality-centredness rather than self-centredness is also common to both concepts. The degrowth movement focuses on economic contraction and deceleration, and thus its scope is narrower and more specific than that of niskāmakarma. Moreover, the degrowth movement rejects economic growth because of its ecologically and socially harmful effects, such as pollution and income inequality, but it is - at least in theory - indifferent to the harmless results of economic activities. On the contrary, the principle of nișkämakarma involves a critical stance toward both good and bad results of actions, insofar as they are pursued because of self-regarding desires. 


\section{Introduction}

This paper discusses the principle of niṣkāmakarma, or "desireless action", in light of the prisoner's dilemma. The dilemma provides a well-formulated, theoretical game context for developing our understanding of desireless action. The results of this discussion will be further tested and examined in this paper in light of the values of the modern environmental and anti-consumerist degrowth movement. The discussion shows that the ancient concept of niṣkämakarma is insightful and instructive when considering topical social and ethical issues, such as degrowth and sustainable development, from a motivation-theoretical perspective. Before exploring the prisoner's dilemma, I offer general remarks on the concept of niṣkämakarma and discuss a philosophically relevant translation issue related to the outcomes of desireless action.

\section{The concept of nișkāmakarma}

The Bhagavadgītā, part of the sixth book of the Hindu epic Mahābhārata, offers a practical approach to liberation (in Sanskrit, mokșa) or freedom from samsāra, the cycle of death and rebirth. This approach is called karmayoga, or the yoga of action. According to it, salvation results from attention to duty and the recognition of past acts upon which the present and the future are based (Singh, 1991, 107). In the Bhagavadgītā, Krishna advocates selfless action as the ideal path to realize the truth about oneself and the ultimate reality. According to Krishna, work done without self-centred expectations or thinking about its outcomes tends to purify one's mind. Moreover, "action without desires" gradually makes an individual fit to see the value of mind control and the benefits of renouncing the work itself $(2.41,2.48-49,6.1-4,6.7,6.24-27)$. The benefits of such renunciation are essentially related to the release from the attachment to worldly bonds and sufferings.

The central tenet of the karmayoga path to liberation is the principle of niṣkāmakarma (“desireless action”). Nișkāmakarma refers to an action performed without any expectation of rewards or results. The Bhagavadgītā calls this "inaction in action and action in inaction (4.18)”. The concept of this detached action is commonly called niṣkāmakarma, even if the term itself is not used in the Bhagavadgītā (Fowler, 2012, p. 
xliii-iv). However, there is reason to state that niṣkamakarma is the central teaching of the Bhagavadgitāa (Chakraborty, 1996, 1998). It is well known that one of the basic beliefs in Hinduism is the law of karma or action. This means that, basically, every good thought, word or deed begets a similar reaction that affects our subsequent lives, and every unkind thought or evil deed comes back to harm us in this life or the next. Three stages of karma are traditionally distinguished. Prärabdha karma refers to the accumulated effects of past deeds that are experienced in the present life. Sañcitakarma refers to acts performed either in this life or in a previous one but which have not yet begun to produce their results or fruits. Āgämikarma refers to acts performed in the present life, the results of which are yet to come. Nișāmakarma is considered to be the best or ideal kind of karma, which can be obtained only by not seeking any rewards (Singh, 1991, 120). Thus, one can gain niṣkāmakarma only by not seeking it.

\section{Different interpretations of nișāmakarma}

In the second chapter of the Bhagavadgìtā, Krishna says that we have rights only to an action and not to its results, whether the results are good or bad (2.47-48). Therefore, we should not desire any results. What is of utmost important here is that human beings are not doomed to idleness or inactivity. Instead, we must act in accordance with the requirements of morality and decency. Yet we are not entitled to the results of our actions and, therefore, should not be selfishly concerned about them. Although it is admirable that we perform the right deeds and participate in the right activities, outcomes (i.e. results and consequences) should not be associated with us. Instead, the positive outcomes of our action are understood in the Bhagavadgita to consist of the common good (3.19-20) that should be accessible to every member of society. Moreover, the outcomes of actions are not ultimately under the control of human beings, but human beings are instruments in the becoming of the ultimate reality, often understood as the fulfilment of God's eternal designs (Bhagavadgìtā 11.15-34) (Singh, 1991, 107). Thus, human beings have the right to use the outcomes of their actions for good, but they do not own those outcomes.

When Krishna's advice that we should not desire any results is read with philosophical sensitivity, the request seems problematic and strange because an action and its results are internally related, as the following example shows. I manage to perform the act of opening 
a window if and only if the window opens by my act. Thus, my opening the window is my bringing about the window's being open (Kim, 1993, p. 26). Accordingly, the relationship between the act and its result is intrinsic.

One could point out that here we have an example of the loose and ambiguous use of language. The Sanskrit term for result in the Bhagavadgītā 2.47 is phala, 'fruit'. Many translations replace it either with the term 'result' or 'reward'. Here, the term 'reward' is related to the idea of universal moral bookkeeping in terms of karmic merits as the basis for a reward. What is clear is that the Bhagavadgìta distinguishes between an act and its outcomes, whether we call those outcomes results, fruits or rewards. Thus, in view of the Bhagavadgitā, doing a deed is one thing, and the result of a deed is another thing. An interpretation that easily comes to mind is that the term 'result' is used vaguely here, incorporating the consequences of an action. Indeed, in addition to the result, an action can have intended or unintended consequences. While the relationship between an act and its result is intrinsic, the relationship between an act and its consequences is extrinsic or causal (von Wright, 1963; Raz, 1975).

Georg Henrik von Wright (1963) explains the difference between the results and the consequences of an act as follows:

By the result of an act we can understand either the change corresponding to this act or alternatively the end-state [...] of this change. Thus by the result of the act of opening a certain window we can understand either the fact that the window is opening (changes from closed to open) or the fact that it is open. On either way of understanding the notion of a result of action the tie between the act and its result is intrinsic. [...] Unlike the relation between an act and its result the relation between an act and its consequences is extrinsic (causal) (p. 39).

To reveal how complicated these issues can be, von Wright adds that one and the same change or state of affairs can be both the result and a consequence of an action. What makes it the one or the other depends upon the agent's intention in acting and upon other circumstances [...] (p. 40). 
Thus, according to von Wright's analysis, the agent's intention decides whether a state of affairs is a result or a consequence of an action. For example, the consequences of opening a window can be fresh air and a fly coming into the room. Fresh air is often an intended consequence, while a fly is, most probably, an unintended consequence.

Based on these initial considerations, Krishna's advice that we should not desire any results can be interpreted in at least three ways. First, it can be interpreted as Krishna telling us to do deeds without striving or taking the trouble to accomplish them. Could this interpretation be correct? I do not think so. Krishna does not advise us to be careless or sluggish or to leave our deeds unfinished. Instead, he suggests that we not focus on our own benefit as an outcome of our actions (but on our duties and the common good, as we will see soon). There is much textual evidence for this interpretation, as the following examples show:

Set thy heart upon thy work, but never on its reward. Work not for reward; but never cease to do thy work. Do thy work in the peace of Yoga and, free from selfish desires, be not moved in success or in failure (2.47-48).

Be free from vain hopes and selfish thought (3.30).

This man of harmony surrenders the reward of his work and thus attains final peace: the man of disharmony, urged by desire, is attached to this reward and remains in bondage (5.12).

He who works not for an earthly reward, but does the work to be done, he is a Sanyasi, he is a Yogi (6.1).

But he who does holy work, Arjuna, because it ought to be done, and surrenders selfishness and thought of rewards, his work is pure, and is peace (18.9).

Moreover, Krishna says that performing actions without entanglement in desires will lead to release from the chains of rebirth (Bhagavadgìtā $2.51 ; 4.18-20$ ). Secondly, it thus seems more plausible to interpret Krishna's request as follows: We should do our deeds not striving for selfish gain and benefit but out of duty (Bhagavadgītā 3.19; 18.9). Even though the Bhagavadgitā thus advises us not to focus on our own benefit, it should be noted that some deeds - for example, those related to fulfilling our basic physical needs such as eating and sleeping - are self-centred, such that completing those actions necessarily 
relate to and include a reference to the self. One may say that, in fulfilling our basic needs, a healthy self-interest is necessary and thus does not go against our duties.

In regard to the Bhagavadgitā's concept of the human person, it is also worth noting that $\bar{a}$ tman or the true, inmost self (who is said in mahāvākyas or the great sayings of the Upanisads to be identical with Brahman or the ultimate reality) is not the agent or doer of deeds but an observer and adviser like Krishna, the charioteer to Prince Arjuna. In the Bhagavadgītā, Arjuna, the commander of the Pandava army, hesitates before the battle at Kurukshetra, as he is shocked at fighting his Kaurava relatives (1.26-2.9). Arjuna orders his charioteer to withdraw, but the man, Krishna, argues with him. Krishna urges Arjuna to ready himself for battle, to regard pleasure and pain, gain and loss, and victory and failure as one and the same. Only when Arjuna has renounced interest in the fruits of his action can he find true peace (2.14-38). This discussion between Krishna and Arjuna has been traditionally understood as implying that the doer of deeds is jivva or the empirical or seeming self, having mind and body. Moreover, according to the Bhagavadgitā, salvation ultimately comes from the recognition that the true self is not jiv $v a$, the doer, and thus the true self does not reap the fruits of action either (2.47). The true or transcendental (or second order) self, ātman, is concerned about moral duties (2.31-39) and focused on observing and evaluating the action of the empirical self, while the empirical self is concerned about obtaining benefits and the results of action (2.2-8). Consequently, salvation is not only an ethical issue in the Bhagavadgit $\bar{a}$ but also a serious ontoepistemological issue: A true understanding of the self and ultimate reality is intrinsic to salvation. To put the foregoing in a nutshell: The Bhagavadgit $\bar{a}$ teaches us that we should do our duty and should advance the common good (lokasangraha, the "welfare of the world", "keeping the world held together well") (3.19-20). At the same time, we should understand that ätman or the inmost self is not the doer of deeds but rather an observer and adviser. (Accordingly, the Bhagavadgītā concept of the true self can be baptized the "Observer and Adviser" concept.)

Let us come back to Krishna's advice that we should not desire any results. Von Wright gives us means for a third interpretation of that request. According to that interpretation, when acting, we should focus on the change corresponding to our act and not on the end state. A suitable metaphor for this interpretation would be the Zen archery competition where the archer is advised to keep his or her attention focused on shooting and not on 
scoring (Herrigel, 1999). Similarly, one can say that the controlled performance of a gymnastics routine is more important than the points or reward given by a jury. In this context, the Western Aristotelian distinction between doing and making (or action and production) appears to be illuminating. Gymnastics as well as dance and music are what Aristotle calls action (Gr. praksis). The result of the action is not separate from the activity itself but included in it. Making or producing (Gr. poieesis), in turn, is an activity in which the result is separate from the activity itself. Such is the case, for example, for house building and thesis writing (Aristotle, 2009, 3, 105-106). In view of the aforesaid, Krishna can be interpreted as advising us that we should concentrate on doing or performing in itself and not keep our sights on the outcome or end state of our activities.

Possible types of situations in which one does something without thinking about the outcome include the following:

1. One does not wait for anything based on one's own action - one just acts (for example, out of duty or gratitude).

2. One is in a flow state or so deeply immersed in what one is doing that one performs an action without thinking about its results or consequences.

3. One acts like an unconscious automaton or robot and does not know or understand what one is doing.

The first two - not waiting for anything and acting in a flow state - are more plausible interpretations of Krishna's request. He does not make a reference to acting unconsciously.

A relevant but seemingly contradictory question is in what way, and to what extent, niskāmakarma or "desireless action" can benefit us. In answering this, we should first note that based on the foregoing analysis, "desireless" does not mean purposeless, indifferent or unintentional. Instead, it means dutiful, i.e. conscientiously or obediently fulfilling one's duty or being motivated by duty rather than by a potential reward. Moreover, we can point out that, because duty implies an obligation, fulfilling one's duty is, by definition, obligatory and necessary. With regard to psychological benefits, acting without desire can produce as by-products freedom from stress, a relaxed performance and life with fewer disappointments because expectations are not directed towards success or failure but towards the fulfilment of duties. The potential risks of acting without desire, in turn, include negligence, impassiveness and too much relaxation. 
Based on the aforesaid, Krishna's advice that we should not desire any results should be interpreted either as the obligation to act unselfishly (for which a suitable motto might be "true love is giving, not receiving") and out of duty or as the request to concentrate on doing and not on the outcome of doing. It should be clear that these two interpretations are compatible and not exclusive: We can both act altruistically and concentrate on the performance of what we are doing.

Earlier in the present paper, I referred to the idea that niṣkāmakarma can be acquired only by renouncing it. In light of this idea, a relevant question is whether nișāmakarma is an ability or a disposition that can be acquired and, if the answer is 'yes', whether nișkāmakarma then requires or presupposes free will. One can have free will at least in the following three senses: (1) as the necessary condition for moral responsibility; (2) as the ability to do otherwise than one did; and (3) as the ability to bring about through one's deeds one's characteristics such as virtues and character strengths. In this context, three relevant interpretations of nișkāmakarma can be distinguished: (a) the disposition of dutifulness; (b) the disposition to advance the common good; and (c) the second-order will or the "Observer and Adviser" concept of the self. Based on what we have already seen, niskāmakarma requires either acting like a robot without considering the results of one's deeds or like a virtuous person who has developed a character that is not oriented towards achieving the results of one's deeds. When so understood, nișkāmakarma requires free will at least in the third sense. Niskāmakarma also seems to relate to the first meaning of free will by emphasizing the importance of fulfilling one's duties. There would be no point in exhorting an automaton to fulfill its duties and responsibilities. The principle of nișāmakarma also presupposes that, in your deeds and actions, you can focus on the results or the performance, and thereby, you can do otherwise than you did. Thus, all three meanings of free will are relevant to and accessible through the concept of niskāmakarma.

Even though we have already achieved a plausible understanding of how to interpret Krishna's advice - "we should not desire for any results" - the prisoner's dilemma provides a means to introduce a fourth interpretation that can be expressed as follows: Be indifferent when choosing between actions, and leave the decision to chance! At face value, this interpretation is problematic because it ignores the focus on duties that is central to Krishna's advice to Arjuna. Nevertheless, to better understand and examine the point of the fourth interpretation, let us consider the prisoner's dilemma. 
4. The prisoner's dilemma

The prisoner's dilemma is a fictional story of a decision-making situation in which individuals seeking their own benefit end up with a worse outcome than could have been achieved through cooperation. In addition, the dilemma is used to demonstrate decisionmaking under risk and uncertainty. Game and decision theorists have actively discussed the prisoner's dilemma and have proposed different analyses. The dilemma was first formulated in 1950 by Merrill Flood and Melvin Dresher and formalized by Albert Tucker (Peterson, 2009; Poundstone, 1992).

According to the story, John and Mary, the accomplices to a crime, have been apprehended and are threatened by imprisonment. John and Mary are unable to communicate; they can remain silent, or they can expose each other. If both remain silent, each will receive a oneyear sentence. However, if one of them confesses, he or she will go free while the partner is jailed for three years. If both confess, each will receive a two-year sentence (cf. Peterson, 2009).

The problem here is that, whatever one chooses, the other had better confess, even though the common good (at least for John and Mary) would be that both remain silent. Thus, here we have two Nash equilibriums in which neither prisoner has anything to gain by changing only his or her own strategy. This situation is illustrated in the table below, where the left-hand number indicates the sentence received by John, and the right-hand number indicates the sentence received by Mary. If both confess, the total sentence is four years, i.e. two years for each; if both remain silent, the total sentence is only two years, i.e. one year for each of them.

Table 1. The strategies and outcomes available to John and Mary

\begin{tabular}{|l|c|c|}
\cline { 2 - 3 } \multicolumn{1}{c|}{} & Mary confesses & Mary remains silent \\
\hline John confesses & 2,2 & 0,3 \\
\hline John remains silent & 3,0 & 1,1 \\
\hline
\end{tabular}


From the table, we can see that, if John remains silent, Mary will be sentenced to one year if she too remains silent, but if she snitches, she will be set free. Again, if John snitches, Mary will be sentenced to three years if she remains silent but only two years if she confesses. Thus, the prisoner who seeks his or her own benefit chooses to snitch and thereby ensures a shorter sentence for himself or herself rather than remaining silent and risking a longer sentence. Although John and Mary act rationally when each seeks his or her own benefit, they face a worse outcome than they would by cooperating (Peterson, 2009).

This collectively suboptimal outcome depends on the absence of an enforceable agreement or intrinsic trust between the prisoners and a lack of information about each other's intentions. Rationality and self-interest force each prisoner to betray the other and, thus, choose an outcome that is worse - for both of them - than the outcome they would receive had they agreed upon cooperating and sought to minimize their total number of years in prison. This demonstrates that what is optimal for each risk-averse individual need not coincide with what is collectively optimal (Peterson, 2009). The prisoner's dilemma helps to precisely recognize and present the two basic strategies of decision-making: focusing on self-interest versus pursuing the common good. Moreover, the dilemma shows that these strategies do not necessarily go hand in hand. This is, in fact, something that Krishna indirectly points out in the Bhagavadgit $\bar{a}$ when he warns us not to work for our own benefit $(2.47 ; 6.1)$.

One might want to defend an even stronger view of the core of the prisoner's dilemma. According to that view, the only genuinely altruistic strategy to achieve the combination of a short sentence and to help one's accomplice is to remain silent, even with the risk that the accomplice may confess, because altruism requires accepting the risk that one's selfinterests remain unfulfilled. Moreover, what is interesting from the perspective of moral theories is that both act and rule utilitarians could support the view that both prisoners should remain silent because, by doing so, the greatest good for the greatest number would be achieved in this particular case (act utilitarianism) and in general (rule utilitarianism) provided that no persons other than those who were mentioned in the story are involved. Kantian deontologists, in turn, could argue that both prisoners ought to tell the truth and confess because telling the truth is a duty, Kant says, and not something to be decided on a case-by-case basis (Groundwork of the Metaphysics of Morals, 4:389, 4:403, 4:441; Kant, 
2002, 5, 19, 58-59). Having said this, it is also important to note the following: It is an arbitrary feature of the dilemma that it is about prisoners, confessing and remaining silent. Of course, we can say that there is a pro tanto or prima facie duty to tell the truth. Despite prison being the surface context of the story, the dilemma is more deeply about the conflict between individual benefit and mutual advantage (Weirich, 2015).

In the context of the prisoner's dilemma, one or the other of the following decision-making strategies is feasible for prisoners who want to follow the principle of desireless action: (A) to be indifferent and to leave the decision to chance (e.g. by arbitrarily drawing lots) or (B) to pursue the common good or the benefit of the other (by remaining silent) instead of seeking to benefit oneself (by confessing). As shown, strategy B is ethically more appropriate and follows Krishna's advice in the Bhagavadgītā, assuming the following: Those who want to act without desire (i.e. the followers of the principle of nișämakarma) can be goal-oriented and target-driven as long as unselfish goals are considered while remaining indifferent and non-attached in regard to personal benefit.

From the perspective of the prisoner's dilemma, the desirelessness of an action has to be addressed in relation to the following options:

1. To act self-interestedly (i.e. in opposition to the common good) and (a) maximize one's own benefit or (b) minimize harm to oneself, or

2. To act collaboratively (i.e. generously towards each other) or altruistically (i.e. benevolently and out of concern for the well-being of the other) and (a) maximize the collective benefit or (b) the benefit of the other.

Confessing and remaining silent are the concrete actions by which these options are realized in the prisoner's dilemma. An indicator of indifference would be that neither of the given options is considered eligible, and neither is sought.

According to the first niṣkāmakarma interpretation of the prisoner's dilemma, "action without desire" means that none of the following are aimed at: one's own benefit, the collective benefit or the benefit of the other. However, if the choice has to be made, a desireless or indifferent way is to draw lots or otherwise leave the decision to chance. Obviously, the Bhagavadgìtā or the principle of nișkāmakarma, for that matter, does not recommend that decisions concerning human action should be reached by resorting to 
chance. Thus, the Bhagavadgit $\bar{a}$ does not recommend the "freedom of indifference" or arbitrary randomness. Instead, we are exhorted to do our duty (Bhagavadgītā 3.19; 18.9).

What, then, is the other way for an action to be desireless? Based on the principle of niskāmakarma, we can answer as follows: We should opt for the second alternative and act collaboratively and altruistically (i.e. with concern for the well-being of others) instead of acting egotistically and self-interestedly. This means that, even if we should not aim at receiving the fruits of our actions for ourselves, we should aim for the common good and the benefit of and positive consequences for others. The following advice from Chapter 3 of the Bhagavadgit $\bar{a}$ states this clearly: "Let thy aim be the good of all, and then carry on thy task in life" (3.20).

However, one may still ask whether an altruistic or collaborative motive for action really represents desireless or disinterested action. One way to answer this is: It depends on the point of view. From a moral point of view, one can say that altruistic action is desireless, because, by definition, it is not based on the desire for one's own benefit. On the other hand, all action requires intention, as Donald Davidson (1980) pointed out, and altruistic or collaborative action is no exception. If one's intention is to maximize the collective benefit or the benefit of the other and if the person so intended knows what (fruits or end state) could make his or her intention true, then he or she intends to perform an action that is not desireless - at least not in any absolute sense - but desired.

David Gauthier (1986) presented the following solution to the prisoner's dilemma. He argued that when the prisoner's dilemma is iterated (or repeated for numerous rounds with the same persons) so that the prisoners come to understand what kind of person the other one is and what his or her decision strategy is likely to be, then it is rational for them to cooperate if each one thinks he or she is playing against a cooperatively minded person. Otherwise, it is rational to play a non-cooperative strategy. Therefore, what is essential here is trust in the other person's co-operativeness. Such trust can be achieved either through one's own observations of the other person's behaviour in repeated decisionmaking situations or through other people's testimony about that person. Gauthier articulated this claim by distinguishing between two kinds of utility-maximizing individuals, namely, straightforward maximizers, who always strive for their self-interest and refuse to cooperate, and constrained maximizers, who cooperate with fellow 
constrained maximizers but not with straightforward maximizers. Moreover, Gauthier argued that individuals will choose to dispose themselves as constrained maximizers rather than straightforward maximizers, that is, to retrain themselves not to think of their self-interest first but rather dispose themselves to honour their agreements if they find themselves in an environment of like-minded individuals (Gauthier, 1986; Peterson, 2009).

When the principle of nișkāmakarma is applied to Gauthier's solution, the following interpretation of the prisoner's dilemma becomes available: Both prisoners should follow the principle of niṣkāmakarma. In Gauthier's terminology, such persons are constrained maximizers because they want to maximize the common good but do not aim at maximizing their individual benefits. However, a reservation must be made regarding this interpretation. Those who follow the principle of nișāmakarma should also cooperate with straightforward maximizers or those who do not follow the principle of niṣkāmakarma and should not cooperate only with like-minded people (i.e. fellow constrained maximizers). This is because only then will the followers of the principle of niṣkāmakarma truly heed Krishna's request that we should not expect any selfish results.

Even though we have already achieved a plausible understanding of how to interpret Krishna's advice - "we should not desire for any results" - the concept of degrowth provides a context in which our understanding of niṣkämakarma can be tested and can shed new light on contemporary environmental and social discussions on the common good and business ethics.

\section{The concept of degrowth}

Concerns about pollution and the depletion of natural resources, among other issues, have prompted many academics and ordinary citizens to re-evaluate the scope and limits of economic growth and more closely scrutinize the notions of sustainable business and sustainable investment (Garriga \& Melé, 2004; Jackson, 2009). The promotion of social justice and the safeguarding of human rights have also been portrayed as demands directed towards companies and industries (Smith et al., 2010). Such demands are justified because, in the global economy, large companies and corporations have 
significant political power and resources that they must use prudently and responsibly. Companies play such a central role in modern societies that attempts to resolve serious global problems never seem to succeed without their cooperation. (However, a capitalismsceptical individual might note that such attempts never seem to succeed with companies either.) The basis of socially responsible businesses and investments is the conviction that companies have social responsibilities and obligations beyond merely generating profits for their owners (Ketola, 2008). Proponents of degrowth also approve of that conviction (Pfister et al., 2016; Kallis, 2017).

Socially responsible businesses and investments pay special attention to environmental and social issues, as well as to issues of corporate governance (e.g. board procedures, accounting frameworks and rules, anti-corruption measures and tax planning). Thus, socially responsible businesses seek sustainability in terms of both social stewardship and economic outcomes. Of course, those joint aims seem conventional and conservative compared to more radical perspectives that question all investment in general. Such interrogation can stem from, for example, social, political and environmental critiques of the market economy, capitalism and financial structures that support the goals of economic growth and are blamed for exacerbating serious social and environmental problems, including income inequality, pollution and climate change (Fotopoulos, 2007). Criticism from that radical degrowth-based perspective suggests the complete elimination of investment, given the assumption that investment logic and practices are always oriented towards growth and profit and, in turn, that no type of financial investment is ultimately sustainable or acceptable. Obviously, in this criticism we can see some similarity to the concept of niskāmakarma, which opposes a self-centred result orientation in human action.

Another branch of the movement for degrowth that represents more moderate criticism of investment and anti-capitalism (Jackson, 2009) is not without historical precedence. An example comes from ancient India. The Law Code of Manu, more famously known as The Laws of Manu (in Sanskrit: Mānava Dharmaśāstra), is generally recognized as the defining document of Brahmanical Hinduism. The Law Code of Manu is dated between the first century BCE and the second century CE (Law Code, 2009, xxiii and xlii-xliii). The concept of dharma or law that appears in the title originally referred to rites and ritual obligations. However, by the time The Law Code of Manu was written, the term dharma 
had assumed a wider meaning, encompassing all that constituted proper conduct and the right way to lead one's life (Law Code, 2009, xviii). This moral dimension of dharma has a central role in The Law Code of Manu. Part of that moral dimension involves instructions concerning the accumulation of wealth.

The Laws of Manu advise us to be unattached to wealth and pleasure and instead to know and follow the law:

The knowledge of the Law is prescribed for people who are unattached to wealth and pleasures; for people who seek to know the Law, scripture is the highest authority (Law Code, 2009, 2.13).

This verse (as well as verses 4.176, 7.26 and 7.151) includes a reference to the trio (trivarga) of law (dharma), wealth (artha) and pleasure ( $k \bar{a} m a$ ) that are the aims or goals of human existence (2.224), later expanded to four with the addition of liberation (moksa) (7.100) (Malamoud, 1981).

The Laws of Manu $(2.136,2.154)$ also teach that knowledge is more important than wealth. Moreover, Brahmins are advised to avoid excessive wealth and instead gather wealth just sufficient for their subsistence (4.3, 4.15). The Laws of Manu warn that the excessive pursuit of wealth and pleasure is unnatural and will result in unhappiness (4.176). However, they are not categorically against profit making, and investment is mentioned as a legal means of acquiring wealth:

Seven means of acquiring wealth are in accordance with the Law: inheritance, finding, purchase, conquest, investment, work, and acceptance of gifts from good people (10.115).

Among major Western philosophers, Aristotle considered acquiring riches with the aim of gaining profit and increasing one's property to be unnatural (Politics I, 9, 1257a-1258b; Aristotle, 1991, 1994-1997). As an alternative, he advocated the philosophy of the golden mean, which considers sufficient income to be a necessary condition for a good life but rejects the pursuit of riches as a policy or practice to achieve that life. In this respect, Manu and Aristotle shake hands. From Aristotle's perspective, mammonism confuses the pursuit of riches with the pursuit of human flourishing, the latter of which supports a life of virtue 
in accordance with reason. Accordingly, pursuing riches should be replaced by more moderate household management. Seen in that light, the moderate degrowth-oriented investment approach (or a "moderate economy" approach) is classical in spirit (both in Indian and Western forms), for it emphasizes limiting and optimising businesses. Notably, moderate degrowth-oriented thinking advocates a limited kind of progressive optimism; unlike proponents of business-as-usual progressiveness, degrowth thinkers such as Tim Jackson and Serge Latouche question the assertion that economic growth is beneficial for whole societies (Jackson, 2009; Latouche, 2009; Redclift, 2000).

Based on these initial observations, degrowth arguably dovetails more naturally with a non-profit than a for-profit orientation in business. However, jumping to that conclusion requires caution, for degrowth does not necessarily need to reject all pursuit of profit. Instead, degrowth suggests that change towards sustainable business and investment practices should be supported insofar as it contributes to generally decreasing production and consumption, reducing pollution or preserving biodiversity. Thus, the paradigm of degrowth can be interpreted as a kind of golden mean that seeks to avoid the extremes of both economic growth and collapse. Notably, degrowth can refer to both the decrease of the economy's biophysical throughput and the decrease of the economy's monetary value measured in GDP. When interpreted as the decrease of the economy's biophysical throughput, degrowth can be understood to tolerate some for-profit investment, including that which helps to preserve natural resources and the rights of future generations. However, when interpreted as the decrease of the economy's monetary value, degrowth can be understood to tolerate for-profit investments that are expected to decrease the value of production in the long run (e.g. investments in recycling industries and low-emission technologies). At the same time, a far stricter understanding of degrowth also exists that is flatly against any growth and for-profit orientation (Georgescu-Roegen, 1971; Latouche, 2009).

The problem with the for-profit orientation is the rebound effect: all accumulation creates more accumulation within a growth-based structure (Heikkurinen, 2014). One could point out that the concept of nișkamakarma can be quite naturally understood to warn about this kind of rebound effect. Accordingly, the concept of niskāmakarma pays attention to the fact that, if we keep our attention focused on the fruits and results of our actions, there is a threat that we will gradually adopt a way of thinking that, at its worst, develops into 
greed or avarice. A similar dynamic characterizes the role of technology used for degrowth. Indeed, asking whether profit is incompatible with degrowth has interesting parallels with asking whether the development of advanced technology is incompatible with degrowth. In that sense, both profit and technology pose problematic cumulative effects that, in a way, are out of control (Heikkurinen, 2016). Because of the path dependencies that it creates, advanced technology tends to prompt more advanced technology, and for the same reason, profit tends to prompt more profit. At the same time, it is exceptionally difficult to control the destination of profit once it has been accumulated. To make profit unproblematic, the global economic system would have to undergo a fundamental change, with progress directed towards a more equal distribution of income and wealth (Piketty, 2014). Obviously, it would be wishful thinking to believe that the concept of nișkāmakarma can solve all the diverse problems of our present economy. However, through its emphasis on performing actions without any expectation of fruits or results such as economic growth, the concept of niskāmakarma sheds light on the requirements for new non-profit-oriented and common-good-oriented economic thinking. In that way, the concept of nișkämakarma can contribute and pave the way to sustainable business and investment.

I have pointed out that the concept of the common good plays a role both in relation to niskāmakarma and degrowth thinking. The question arises whether we should always advance the common good. Because of limited space, I will offer only a brief remark on this topic. In a liberalist framework that is prominent in free-market capitalism, advancing the common good can be one's duty basically only if it does not violate anyone's individual rights. We have seen that degrowth thinking advocates instead a more communitarian framework for our rights and duties, recognizing common moral values and collective responsibility. In view of our analysis above, this latter framework also dovetails well with nișkāmakarma.

\section{Summary}

We have discussed the Bhagavadgit is performed without expectation of reward. In the Bhagavadgitāa, Krishna says that we have rights only to an action and not to its results, whether those are good or bad (2.47). Therefore, we should not desire any results. In this paper, we have distinguished between 
different interpretations of Krishna's request. Based on the textual evidence, the statement that we have rights only to an action and not to its fruits should be interpreted either as the obligation to act unselfishly and out of duty or as the request to concentrate on doing and not on outcome. The prisoner's dilemma shows that, of these two interpretations, the dutybased or common-good-oriented interpretation is the more advantageous because following it maximizes the collective benefit.

Moreover, we have drawn a comparison between the principle of nișāmakarma and the values of the modern environmental and anti-consumerist degrowth movement. A nonprofit orientation and the emphasis on duties are shared by the concepts of degrowth and nișkämakarma. Social- or reality-centredness, rather than self-centredness, is also common to both concepts. However, there are also relevant differences between these two concepts. The degrowth movement focuses on economic contraction and deceleration, and thus its scope is narrower and more specific than that of niskāmakarma. In addition, the degrowth movement rejects economic growth for its ecologically and socially harmful effects such as pollution and income inequality but is - at least in theory - indifferent to the harmless results of economic activities. On the contrary, the principle of niṣkāmakarma involves a critical stance towards both the good and bad results of actions, insofar as they are pursued because of self-regarding desires.

\section{References}

Aristotle (2009). The Nicomachean Ethics. Translated by David Ross, revised by Lesley Brown. Oxford: Oxford University Press.

The Bhagavad Gita (1994). Translated by Juan Mascaró. New Delhi: Penguin Books India. Chakraborty, Shitangshu K. (1996). "Human values and Indian ethos". In: Wojciech Gasparski \& Leo V. Ryan (eds.), Human Action in Business: Praxiological and Ethical Dimensions, Praxiology: The international annual of practical philosophy and methodology 5, New Brunswick, NJ: Transaction Publishers, 171-196.

Chakraborty, Shitangshu K. (1998). "Ethics for business and management: Explorations in Hindu thought”. In: Brij Nino Kumar \& Horst Steinmann (eds.), Ethics in International Management, Berlin: Walter de Gruyter, 281-308. 
Davidson, D. (1980). Essays on Actions and Events. Oxford: Oxford University Press.

Fowler, J. D. (2012). The Bhagavad Gita: A Text and Commentary for Students. Eastbourne: Sussex Academy Press.

Garriga, E., \& Melé, D. (2004). Corporate social responsibility theories: Mapping the territory. Journal of Business Ethics 53(1-2), 51-71.

Gauthier, D. (1986). Morals by Agreement. Oxford: Clarendon Press.

Georgescu-Roegen, N. (1971). The Entropy Law and the Economic Process. Cambridge, MA: Harvard University Press.

Heikkurinen, P. (2014). Kestävyyden käsitteen ulottuvuudet [The dimensions of the concept of sustainability]. Tieteessä tapahtuu 32(4), 10-16.

Heikkurinen, P. (2016). Degrowth by means of technology? A treatise for an ethos of releasement. Journal of Cleaner Production, published online at: https://doi.org/10.1016/j.jclepro.2016.07.070.

Herrigel, E. (1999). Zen in the Art of Archery. New York: Vintage Books.

Jackson, T. (2009). Prosperity without growth? The transition to a sustainable economy. London: Sustainable Development Commission.

Kallis, G. (2017). Degrowth. Newcastle-upon-Tyne: Agenda Publishing.

Kant, I. (2002). Groundwork of the Metaphysics of Morals, ed. and transl. by A. W. Wood. New Haven: Yale University Press.

Ketola, T. (2008). A holistic corporate responsibility model: Integrating values, discourses and actions. Journal of Business Ethics 8o(3), 419-435.

Kim, J. (1993). Supervenience and Mind: Selected Philosophical Essays. Cambridge: Cambridge University Press.

Latouche, S. (2009). Farewell to Growth. Cambridge: Polity Press.

The Law Code of Manu (2009). Translated by Patrick Olivelle. Oxford: University Press.

Malamoud, C. (1981). On the rhetoric and semantics of purușārtha. Contributions to Indian Sociology, 15, 33-48.

Peterson, M. (2009). An Introduction to Decision Theory. Cambridge: Cambridge University Press. Pfister, T., Schweighofer, M., \& Reichel, A. (2016). Sustainability. Abingdon: Routledge.

Piketty, T. (2014). Capital in the Twenty-First Century. Cambridge, MA: Belknap Press. 
Poundstone, W. (1992). Prisoner's Dilemma: John von Neumann, Game Theory, and the Puzzle of the Bomb. New York: Anchor Books.

Raz, J. (1975). Practical Reason and Norms. Oxford: Oxford University Press.

Redclift, M. (2000). Sustainable Development: Exploring the Contradictions. London: Routledge.

Singh, D. V. (1991). Hinduism: An Introduction. Jaipur: Surabhi Prakash.

Smith, A., Voß, J.-P., \& Grin, J. (2010). Innovation studies and sustainability transitions: The allure of the multi-level perspective and its challenges. Research Policy 39(4), 435-448.

Weirich, P. (2015). “The lesson of the prisoner's dilemma”. In The Prisoner's Dilemma, ed. M. Peterson. Cambridge: Cambridge University Press, pp. 265-281.

von Wright, G. H. (1963). Norm and Action: A Logical Enquiry. London: Routledge \& Kegan Paul. 